\title{
Design of Energy System Introducing Biomass Resources for a Rural Area
}

\author{
Kazuo KuBO, and Toshihiko NAKATA \\ (Received March 22, 2004) \\ 地域特性を考慮したバイオマス利用システムの構築 \\ 久保一雄，中田俊彦
}

\begin{abstract}
The study focuses on the design of renewable energy systems introducing biomass resources for a rural area in Japan. In an energy-economic model, woody biomass and animal manure (livestock and poultry manure) have been introduced to supply stable power, combining with wind and PV etc. Intermittency of climate conditions and the changes in demand of electricity are carefully considered to examine cost effective systems for the area. As a result, we have found that gasification of woody biomass can supply electricity at a reasonable cost, and the biogasification of animal manure becomes cost effective provided inverse onerous contract of the waste is available. The renewable energy system reduces the carbon emissions by $65 \%$, and reduces the annual cost of the entire system by $15 \%$.
\end{abstract}

\section{Key Words}

Biomass energy, Renewable energy, Local energy system

\section{1. 本研究の背景および目的}

バイオマスは，化石資源のように高密度集中型の資源では なく, 広く希薄に分散して存在する低密度分散型の物質であ り，エネルギー資源である。そのため，バイオマスを利用す る場合には，バイオマスの収集および輸送にかかる手間やコ ストが非常に大きな問題となる。バイオマス資源は, 発生し た地域にて, 工業原料, 材料, 製品へと変換され, 消費, 出 荷され，可能な限り循環利用される。また，エネルギーを取 り出して, 地域にエネルギーを供給することができる。この ように，地域内に発生したバイオマスはその地域内にて利用 するのが適していると考えられ，バイオマスを基盤とした循 環型システムは当然地域性を反映したものになる。

したがって，地域に適した循環型システムの形成のために は, 気候条件, エネルギー需要, 生活様式, インフラ整備と いった地域特性を十分に考慮してバイオマスの利用システム を構築することが必要である。しかし，現在行われているの は国内のバイオマス資源の賦存量の推計等の包括的な調査, 研究が中心であり, 地域特性を考慮したものはほとんど見あ たらない。そこで本研究では, 解析モデルを考案し, 地域特

Tohoku University

6-6-01, Aoba, Aramaki, Aoba-ku, Sendai-shi, Miyagi 980-8579, Japan
性を考慮したバイオマス利用システムの設計を行った。バイ オマスや地域に存在するその他の再生可能エネルギーを利用 する地域電力供給システムを考案し, そのシステムの運用特 性の解析やシステムの導入により地域に及ぼす影響の評価を 行う。また, 循環型社会の実現に向けた施策の検討を行う。

\section{2. 地域電力供給システム}

\section{1 対象地域}

本研究では, 岩手県暮巻町を対象として解析した。この町 には 2,958 世帯, 8,808 人 (平成 16 年 1 月 1 日現在) が暮らし ている。東北一の酪農の町であり, 主な産業は酪農を中心と した第一次産業である。岩手県統計年鑑1)によれば，平成 14 年度農業粗生産額の約 4 分の 3 を畜産関係が占めており, さ らにその生産物である牛乳は，〈ずまきブランドとして関東

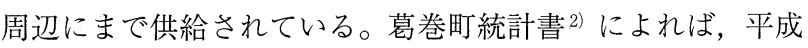
14 年度工業出荷額に占める食料品製造業は $70 \%$ を超えてい る。現在, 約 10,000 頭の乳牛が飼育されており, 家畜から排 出される䔬尿は堆肥として利用されているが, 野積みされた 状態で保管され, 悪臭等の問題を引き起こしている。また, 森

東北大学大学院工学研究科技術社会システム専攻

于 980-8579 宮城県仙台市青葉区荒巻字青葉 6-6-01 
林面積は町の全面積の $85 \%$ を占め, 森林資源も豊富に存在し ている。周辺の山々は非常に風が強く, 葛巻町新エネルギー ビジョン3) では町東部の袖山高原で年平均 $7.9 \mathrm{~m} / \mathrm{s}$ の風速が観 測されることが示されている。

\section{2 対象地域のバイオマス賦存量}

前節にて示したように対象地域では多くの乳牛が飼育され ている。これらの乳牛等の家畜から排出される䔬尿の量は，1 日約 517 トン, 年間で約 18 万 8,500 トンと推定される。これ らの家畜粪尿はメタン発酵させることによってエネルギーと して利用可能であり, 同時に畜産廃棄物処理の推進にもつな がる。

また，葛巻町の森林面積は約 3 万 7,000ha で全面積の $85 \%$ を占める。そのうち，人工林が $44 \% を$ 占めており，これらの 適切な保育, 間伐が必要となる。これらの森林資源は, 現在, 木材として使用されるのみならず，木炭の生産販売や家庭用 の薪としてエネルギー利用が行われている。また，町内には チップ生産工場から排出される樹皮を利用したバークペレッ トを生産している工場も存在する。

製材くずはペレットに加工されているため, 現在未利用と なっている森林資源を新たに木質バイオマスとして利用する ことができる。特に間伐材が木質バイオマス資源として有力 であり, 葛巻町の調査の結果 ${ }^{3)}$, その年間発生量は, 搬出の比 較的容易なものに限定した場合, 約 $6,000 \mathrm{~m}^{3}$ 程度と推定されて いる。

\section{3 地域電力供給システム}

本研究では対象地域に電力供給を行う地域電力供給システ ムを考案した。システムは木質バイオマス直接燃焼発電, 木 質バイオマスガス化発電, 畜産バイオマス消化ガス発電, 太 陽光発電, 風力発電, 系統電力から構成される。Fig. 1に考案 した地域電力供給システムのモデル図を示す。

利用するバイオマス資源は，木質バイオマスとして間伐材， 畜産バイオマスとして家畜霬尿を対象とする。

バイオマス発電を行う際には, 電力以外に廃熱が発生する。 熱を電力とあわせて供給する熱電併給システム (CHP) とす ることも可能であるが，本システムは電力供給に特化したシ

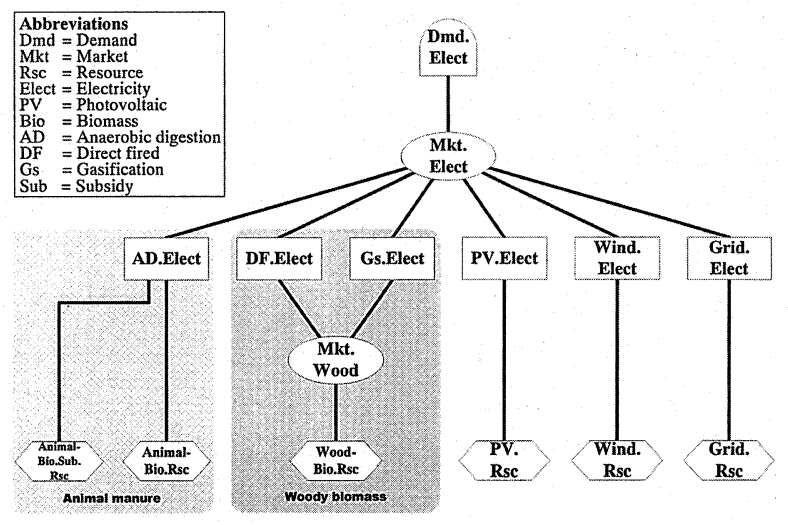

Fig. 1 Network of renewable energy system
ステムである。

バイオマス発電施設における熱需要として，木質の場合に は間伐材の予備乾燥があり，畜産の場合には発酵層の保温が ある。本研究は, 電力部門に特化したシステムの構築を主眼 としているため，こうした熱需要（すなわち消費電力あるい は燃料）は, Table 1 に示す技術パラメー夕の効率に含めて提 案している。

\section{3. 解析方法}

\section{1 解析ツール}

解析ツールとして, 米国ローレンス・リバモア国立研究所 と共同開発中のエネルギー経済モデル META・Net ${ }^{4)}$ を使用し た。

META・Net は，生産，消費システムの解析を簡略化する目 的で開発されたエネルギー経済モデルである。システムは，資 源生産，変換技術 (たとえば，石炭から電力），需要，市場を 模擬したノードをネットワーク化することによってモデル化 できる。各ノード間を結ぶことによって，ものの物理的な動 き（流通）を表すことが可能になる。たとえば，ガス資源を 表すノードとガス火力発電所を表すノードを結ぶことによっ て，発電所にガスが供給されることを模擬することができる。 また，ノード間では価格に関する情報のやり取りも行う。こ のネットワーク手法がモデルの構築，修正，解析を容易なも のとしている。

エネルギーシステムの運用特性の解析を行うために，1時 間ごとの需要デー夕，日射量デー夕，風況デー夕を，それぞ れ 1 年間 (8,760 時間) 分のデー夕を用いて解析を行う。した がって, 需要の変動や自然条件の変動を考慮して, エネルギー システムの設計を行うことが可能である。そして，各発電設 備の建設費，運転維持費等のコストや発電効率を考慮して， もっとも経済的なシステム構成，システム運用を導くことが 可能である。

\section{2 設定条件}

\subsection{1 解析期間}

解析の対象期間は 1 年間として解析を行った。解析に使用 するエネルギー経済モデルは多期間均衡モデルであるため, 対象期間の 1 年間を “period”に分割する必要がある。本研究 では， 1 period $=1$ 時間として， 1 年間を 8,760分割して解析 を行う。

\subsection{2 地域電力需要}

本研究では，2000 年度の需要デー夕に基づいて解析した。 データは葛巻町統計書 ${ }^{2}$ に記載のものを使用した。東北電力 総需要実績 (平成 12 年度) から，春秋期 ( 4 月， 5 月，9月， 10 月，11月， 3 月)，夏期 ( 6 月， 7 月， 8 月)，冬期 (12月， 1 月，2月)の 3 期についてそれぞれ平日，休日の計 6 パター ンの需要カーブを想定し，8,760時間分の電力需要デー夕を作 成した。2000年に同町における電力消費量の実績值は，29,310 MWh である。 


\subsection{3 日射量}

対象地域の葛巻中学校には, すでに $50 \mathrm{~kW}$ の太陽光発電シ ステムが導入されている。本解析における太陽光発電の発電 量の算出には，この太陽光発電システムの実績デー夕を用い ている。

\subsection{4 風 況}

地域内の袖山高原では，第 3 セクターが実施主体となって， 風力発電が行われている。本解析に扔ける風力発電の発電量 の算出には, 発電事業者から提供された風況デー夕を使用し ている。

\subsection{5 発電設備のコストおよび性能值}

各発電設備のコストや性能值は文献やNEDOのデータベー 久等5) 12) に基づいて設定した。設定した各発電設備のコス トおよび性能值を Table 1 にまとめる。

\subsection{6 資源価格}

(1)木質バイオマス

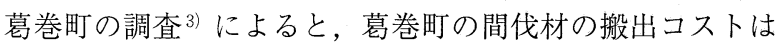
8,000 円 $/ \mathrm{m}^{3}$ と報告されており，この価格を間伐材の利用価格 と設定する。

町内の賦存量を超えて利用する場合は，近隣の市町村から 間伐材を購入する必要がある。間伐材そのものの価格は町内 に拈いて発生するものと等しいと仮定し，平均 $40 \mathrm{~km}$ の輸送 が必要であると想定し，輸送費を加えたものが町外で発生す る間伐材の価格である。輸送費は, 文献13) より1トンあたり 抢よそ10,000円/50kmであることから，8,000円/ton と設定 する。

(2)畜産バイオマス

家畜糞尿は，酪農家から無償で入手することができ，搬出 コストは，酪農家が負担すると仮定した。酪農家の金銭的負 担を軽減するためには何らかの助成制度が必要であるが，制 度の仕組みやコストが現時点では不確定な部分が多いため,
本研究では考慮していない。

(3) 系統電力

系統電力の価格は, 東北電力の従量電灯の基本料金を電気 料金単価表 ${ }^{14)}$ から算出し, 21.6 円 $/ \mathrm{kWh}$ と設定する。

以上の各資源の資源価格を Table 2 にまとめる。

\subsection{7 $\mathrm{CO}_{2}$ 排出原単位}

$\mathrm{CO}_{2}$ 排出量の算出に用いる $\mathrm{CO}_{2}$ 排出原単位を Table 3 に示 す。系統電力の使用によって排出される $\mathrm{CO}_{2}$ の排出原単位は, 東北電力の 2000 年度の值 ${ }^{15)}$ を使用する。バイオマス資源の 燃焼による $\mathrm{CO}_{2}$ はカーボンニュートラルの特性によってゼロ とみなし，システムの $\mathrm{CO}_{2}$ 排出量には考慮に入れない。また， システムの運用には木質バイオマスの伐採, 収集, 輸送といっ た作業が必然的に伴う。その作業に際して発生する $\mathrm{CO}_{2}$ の排 出原単位は文献 ${ }^{16)}$ の值を利用する。

なお，評価対象となる $\mathrm{CO}_{2}$ は，システムの運用に際して排 出されるものだけであり, 発電設備の建設等によって排出さ れる $\mathrm{CO}_{2}$ は考慮しない。

\section{3 留意事項}

この地域電力供給システムは, 特定電気事業に該当し, 経 済産業大臣の認可が必要である。また，電気主任技術者を選

Table 2 Resource price

\begin{tabular}{lc}
\hline \multicolumn{1}{c}{ Resource } & Price (JPY/kWh) \\
\hline Thinned wood (inside Kuzumaki) & 2.93 \\
Thinned wood (outside Kuzumaki) & 4.31 \\
Animal manure & 0 \\
Grid electricity & 21.6 \\
\hline
\end{tabular}

Table $3 \quad \mathrm{CO}_{2}$ emission factor

\begin{tabular}{c|ll}
\hline Resource & \multicolumn{2}{|c}{ Emission factor } \\
\hline Grid electricity & $1.16 \times 10^{-1} \mathrm{TC} / \mathrm{MWh}$ \\
Woody biomass & $2.16 \times 10^{-3} \mathrm{TC} / \mathrm{MWh}_{\text {fuel }}$ \\
\hline
\end{tabular}

Table 1 Cost and performance of generation technologies

\begin{tabular}{|c|c|c|c|c|c|c|}
\hline Component & Life (year) & \begin{tabular}{|c}
$\begin{array}{c}\text { Specific capital cost } \\
(\mathrm{JPY} / \mathrm{kW})\end{array}$ \\
\end{tabular} & $\begin{array}{c}\text { Fixed operating cost } \\
(\mathrm{JPY} / \mathrm{kW} / \mathrm{yr})\end{array}$ & $\begin{array}{c}\text { Variable operating cost } \\
(\mathrm{JPY} / \mathrm{kWh})\end{array}$ & $\begin{array}{c}\text { Efficiency } \\
(\%)\end{array}$ & Reference \\
\hline Woody biomass* & & & & & & (A) \\
\hline Direct fired & 20 & 480,000 & 35,600 & 1.17 & 28 & (B) \\
\hline Gasification & 20 & 700,000 & 18,200 & 1.18 & 36 & (C) \\
\hline Animal manure** & & & & & & (A) \\
\hline Anaerobic digestion & 20 & $4,770,000$ & 70,600 & 14.6 & 25 & (D) \\
\hline PV & 20 & 870,000 & 2,300 & 0 & - & $(\mathrm{E})$ \\
\hline Wind & 20 & 240,000 & 6,200 & 0 & - & $(\mathrm{E})$ \\
\hline
\end{tabular}

* Density: 0.47 (t/m3), Heating value: $4.99(\mathrm{kcal} / \mathrm{t})$

** Generated biogas: 456 (m3/cow-yr), Heating value: $6,000(\mathrm{kcal} / \mathrm{m} 3)$

A) Kuzumaki New Energy Vision, Kuzumaki town, Iwate, (1999)

B) Noshiro Cooperative Association for Utilization of Woody Resources, Noshiro city, Akita, (2002)

C) Research Institute of Innovative Technology for Earth (RITE), (2000)

D) Yagi Public Corporation, Yagi town, Kyoto, (2002)

E) New Energy and Industrial Technology Development Organization (NEDO), (2003) 
任する必要がある。さらに，電力系統への連系を想定してい るため, 電力系統連系技術要件ガイドラインに沿って, 系統 運用者と協議を行う必要がある。

\section{4. 解析結果}

\section{1 最適設備構成と年間供給電力量}

Table 4にシステムを構成する各設備の最適設備容量と年間 供給電力量を示す。システムの主要な電源は風力発電であり, 設備容量は他の電源に比べかなり大きい。年間供給電力量で も全体の $43 \%$ を占める。

バイオマス発電のなかでは，木質バイオマスガス化発電の 発電量が最も大きいことが明らかとなった。木質バイオマス を利用した発電として, ガス化発電のほかにも直接燃焼発電 の導入の可能性を検討したが，直接燃焼発電の供給電力が全 体に占める割合は $1 \%$ 程度で，ガス化発電と比較すると供給 量に20倍弱の差がある。直接燃焼の熱効率は, 発電量が小さ い場合には, Table 1で示した值よりもさらに小さくなる。本 研究にて想定する市場では, 割安な電力が優先的に選択され るため, 発電コストが割高な直接燃焼の導入量が極端に小さ くなった。

また，畜産バイオマス消化ガス発電はほとんど導入されな いことが明らかになった。他の発電設備に比へ，非常にコス トが高いために採算が合わず，経済的には導入が困難である と考えられる。

\section{2 電力供給システムの運用特性}

Fig. 2に電力供給システムの電力供給特性を示す。グラフの 期間は 2000 年 4 月 3 日から同 9 日までの 1 週間である。Fig. 3では同期間の各発電設備の電力供給価格を示す。Fig. 2 の各 時間における各設備の電力供給量はこの価格によって決定さ れている。

木質バイオマス直接燃焼発電と木質バイオマスガス化発電 は多くの時間をほぼ一定の出力で運転している。このため, 電 力供給システムに执いてバイオマス発電はベース電源として の役割を果たしているといえる。

木質バイオマス発電によって供給される電力，つまりベー 久電源分を除いた需要が風力発電と系統電力によって賄われ ている。風力電力の発電量は入力データで用いた風況デー夕 に依存しており，風力発電だけで需要を満足できない時間帯 が存在する。この時間帯において, 需要に対して風力発電の 発電量の不足分を系統電力が補っている。

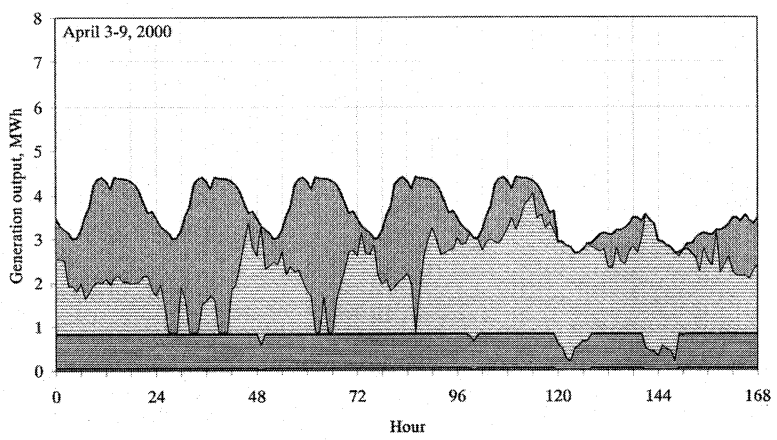

$\square$ Direct fired $\square$ Gasification $\square$ Anaerobic digestion $\square \mathrm{PV} \square$ Wind $\square$ Grid -Elect demand

Fig. 2 Electricity generation in early April

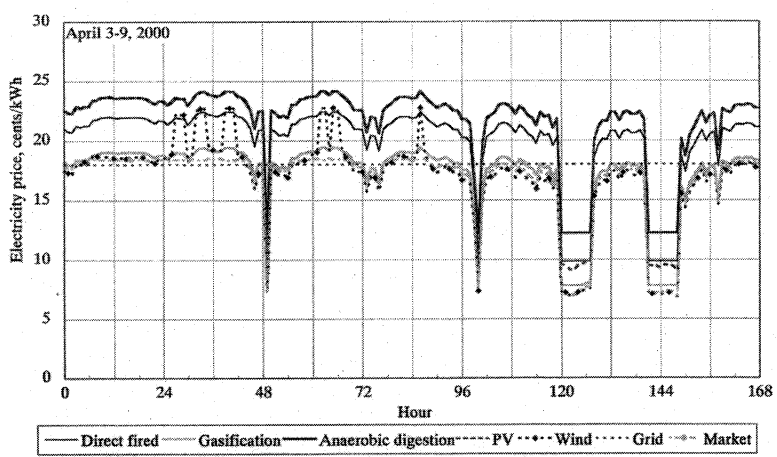

Fig. 3 Electricity marginal cost in early April

風速が大きい時間帯では, 風力発電の出力と木質バイオマ ス発電の最大出力の和が需要を上回る時間帯が存在する。風 力発電と木質バイオマス発電の電力供給価格を比較した場合, 風力発電の価格のほうが安いために, この時間帯では風力発 電の電力をすべて利用して, バイオマス発電の出力を下げて 運転することになる。

\section{3 バイオマス資源の消費量}

4.3.1 木質バイオマス

木質バイオマスの消費量は，年間に熱量ベースで 18,530 MWh である。これを体積換算すると $6,790 \mathrm{~m}^{3}$ である。本解析 では対象地域内での間伐材の利用可能量を年間 $6,000 \mathrm{~m}^{3}$ と設定 しているが，その制約を超えて間伐材が消費される。つまり， 対象地域外の間伐材が約 $800 \mathrm{~m}^{3}$ 消費される。

\subsection{2 畜産バイオマス}

消化ガス発電の燃料として消費されるバイオガスの量は,

Table 4 System capacity configuration and annual generation

\begin{tabular}{l|c|c}
\hline & Capacity [MW] & Annual generation [MWh] \\
\hline Woody biomass - Direct fired & 0.045 & 337 \\
Woody biomass - Gasification & 0.762 & 6,231 \\
Animal manure - Anaerobic digestion & 0.011 & 77 \\
PV & 0.071 & 89 \\
Wind & 8.67 & 12,594 \\
Grid & 3.999 (Peak) & 10,013 \\
\hline
\end{tabular}


年間に熱量ベースで $310 \mathrm{MWh}$ である。これを体積換算すると 47,840 $\mathrm{Nm}^{3}$ である。この量のバイオガスを発生させるために必 要な牛の頭数は乳用成牛 110 頭である。葛巻町では約 10,000 頭の乳牛が飼育されていることを考慮すると, 畜産バイオマ スは，ほとんど導入されない結果になった。循環型社会の形 成のためには，バイオマス資源を有効利用する必要があり，利 用の促進にはコスト低減や助成制度が欠かせないと考えられ る。

\section{4 地域電力供給システムの $\mathrm{CO}_{2}$ 排出量}

Fig. 4に地域電力供給システムの導入前後の $\mathrm{CO}_{2}$ 排出量の変 化を示す。地域電力供給システムの導入前, つまり系統電力 のみで電力供給が行われる場合は, 系統電力の消費量と $\mathrm{CO}_{2}$ 排出原単位（0.116TC／MWh）を乗じたものがそのままシス テムの $\mathrm{CO}_{2}$ 排出量である。地域電力供給システムの導入前で は，年間に 3,400 炭素トンの $\mathrm{CO}_{2}$ が排出されると推定できる。

一方, 地域電力供給システムの導入後では, 系統電力の消 費による $\mathrm{CO}_{2}$ だけでなく，木質バイオマス，つまり間伐材の 伐採，輸送にかかる $\mathrm{CO}_{2}$ の排出量を考虑に入れる必要がある。 これらを考慮して算出した $\mathrm{CO}_{2}$ 排出量は 1,200 炭素トンであ る。システムの導入により年間約 2,200 炭素トンの $\mathrm{CO}_{2}$ が削減 可能となり，削減率にして $65 \%$ にものぼ。

\section{5 地域電力供給システムの年間システムコスト}

Fig. 5に従来型の電力供給システムの年間システムコストと 地域電力供給システムの年間システムコストを示す。

従来型の電力供給システムでは, 電力はすべて系統電力に よって供給されるため, 計上コストは年間電力消費量と系統 電力単価の積である。これにより，対象地域全体で発生する 電力コストは年間 6 億 3,300 万円である。

一方, 地域電力供給システムにおいては, 自ら発電設備を 建設し，運転を行うため，それらに必要な建設費，運転維持 費，燃料費等のコストが発生する。建設費は設備容量と比建 設費（Specific capital cost：SCC）の積から求め，その費用は すべて借入金により賄うものとする。設備の耐用年数に等し い期間を返済期間と設定し， 1 年あたりに必要な返済額を建 設費として計上している。返済に扔ける利子率は $5 \%$ と設定

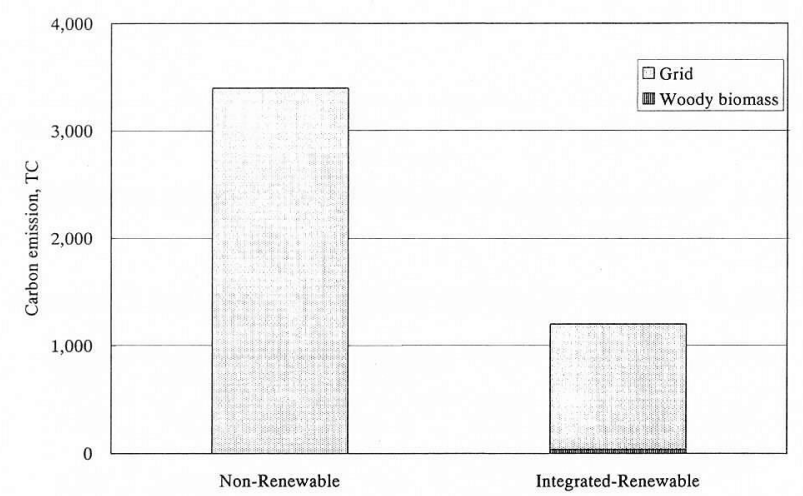

Fig. 4 Annual $\mathrm{CO}_{2}$ emissions from the non-renewable and renewable systems

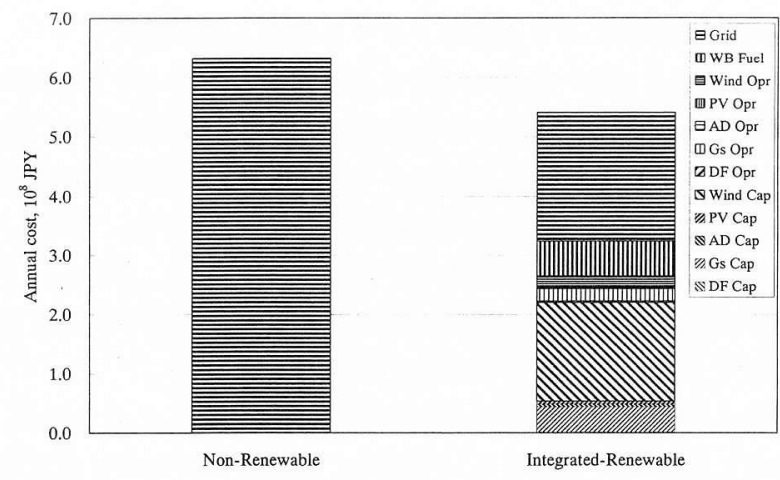

Fig. 5 Comparison of annual system costs

している。運転維持費, 燃料費に関しては設備容量, 発電設 備の供給電力量, 燃料消費量とそれぞれの単価からコストを 算出している。この手法によって地域電力供給システムの年 間システムコストは 5 億 4,100 万円と算出される。

地域電力供給システムの導入によって地域の電力コストは 9,200万円のコスト削減が可能となり，15\%の削減効果が期待 できる。

\section{6 木質バイオマス発電の設備費の変動による発電量の変 化}

バイオマスを利用した発電技術は，化石然料利用に比べて 未成熟な技術であり，今後の市場の技術の成熟に伴ってコス トが低下していくものと考えられる。その発電コストは, 建 設費，運転維持費，燃料費から構成され，なかでも，建設費 が最も大きな割合を占めている。そこで，直接燃焼発電とガ ス化発電の建設費をそれぞれ $30 \%$ 削減した場合の発電量の変 化を解析し，バイオマスの建設費の変化が発電コスト（すな わち発電量）に及ぼす影響を明らかにした（Fig. 6)。同図か ら，ガス化燃焼が直接燃焼よりも経済性に優れ，直接燃焼の 導入は，本検討範囲では，ほとんど期待できないことがわか る。

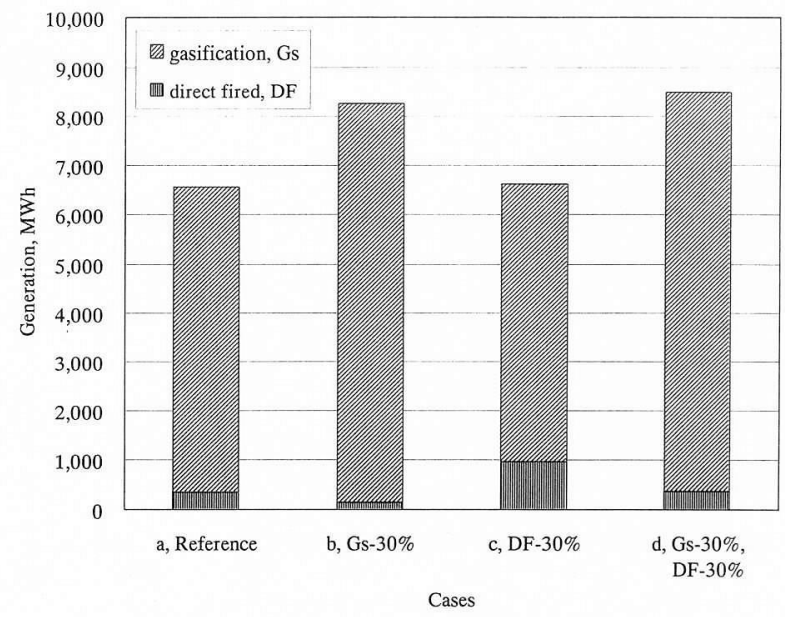

Fig. 6 Annual electric generation by woodof gasification and direct fired combustiondirect fired 


\section{7 逆有償による畜産バイオマスの導入量の変化}

“家畜排せつ物の管理の適正化及び利用の促進に関する法律 (家畜排せつ物法)”により平成 16 年 11 月から家畜排せつ物 の野積みが禁止されることにより, 家畜䔬尿の適切な処理方 法が必要となる。また, 循環型社会形成のためにも, 大量に 発生する家畜䔬尿の有効利用が求められている。これらの背 景からも消化ガス発電設備の導入量の拡大は必須のものであ ると考えられ，何らかの方策が必要である。

畜産バイオマス発電の導入の阻害要因となっているのは, 非常に高いコストである。本研究で設定した消化ガス発電設 備のコストは, 他の発電設備に比べ群を抜いて高い。この設 備が経済的にシステムに導入されるためには, 高いコストを 補うだけの収入が必要である。牛糞を無償で引き取ると設定 した場合では，コストに見合った収入が得られなかった。そ こで，無償で引き取っていた家畜排泄物の引き取り価格（又 は処理料）を有償とする（以下 “逆有償”という）ことを想 定し, その逆有償価格によって消化ガス発電の導入量がどの ように変化するのか解析を行う。

Fig. 7に逆有償価格と消化ガス発電の発電量を示す。逆有償 価格が 2,000 円/ton 以下では発電量にほとんど変化が見られ ない。逆有償価格が 2,100 円/ton の場合, 発電量がやや増加 し，無償引き取り時の約 10 倍である770MWhの電力が発電さ れる。逆有償価格が 2,200 円/tonの価格帯で急激に発電量が 増加し，2,200 円/ton では 3,630MWh，2,250 円/ton では $5,630 \mathrm{MWh}$ と大幅な発電量の増加を示す。逆有償価格が 2,300 円/tonでは $6,120 \mathrm{MWh}$ の電力が発電され, それ以上価格が上 昇してもほとんど発電量に変化が見られない。発電量が 6,000MWh 以上の場合, 設備の発電効率が $25 \%$ あるるとを 考えると, 対象地域内で発生する家畜粪尿がほとんど消費さ れる。資源制約により価格が上昇しても発電量はほとんど変 化しないと考えられる。

対象地域内で発生する家畜䔬尿がほとんど消費されるとき の逆有償価格，つまり 2,300 円/tonのときの処理料収入を算 出し, Table 5に算出結果を示す。発電事業者の処理料収入は 約 4 億4,000万円と大きいが, 酪農家の立場からみれば膨大な コストとなる。畜産廃裹物法が施行されるためとはいえ，農 業生産額に対して 1 割以上の支出となり, 酪農家はこの支出

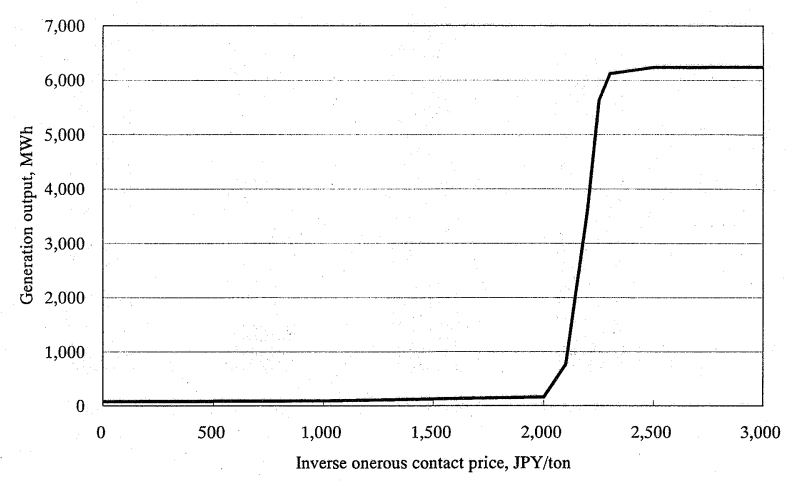

Fig. 7 Anaerobic digestion generation as a function of inverse onerous contract price
Table 5 Burden of waste disposal for dairy farmer \begin{tabular}{l|l}
\hline Charge for disposing livestock manures (A) & JPY $4.4 \times 10^{8}$
\end{tabular} Income from dairy farming (B) $\mathrm{A} / \mathrm{B}$ Cost per dairy farm household JPY $3.6 \times 10^{9}$ $12 \%$ JPY $1.6 \times 10^{6}$

増加を容易には受け入れ難いと考えられる。したがって, 酪 農家の負担を軽減する施策が必要であると思われる。一方で, 引き取り価格を高めに設定した場合には，市場原理が働き，酪 農家が尿を分離したり風乾したりする重量削減努力が始まる ので，必ずしも高負担にはならないだろう。引き取り貲尿が 濃厚化すれば, 取得メタンガス量が増大するので, 消化ガス 発電の採算性が向上することが期待できる。

\section{8 補助金による逆有償価格の変化}

消化ガス発電の建設費に補助金を適用する場合, 減価償却 費が減少するため, 逆有償価格が低下し, 酪農家が負う負担 が軽減されると考えられる。

Fig. 8に建設費に対する補助率と逆有償価格を示す。眓中に 示す価格は消化ガス発電の発電量が 6,000MWh 超える最低 逆有償価格である。

逆有償価格は設備に対する補助率の増加に伴ってほぼ線形 的に低下する。逆有償価格は, 補助を行わない場合 2,300 円 / tonであったものが, 補助率 10\%では 2,100 円/ton, 補助率 $30 \%$ では 1,700 円/ton, 補助率 $50 \%$ では 1,250 円/ton となる。 補助率が $75 \%$ の場合では, 逆有償価格は 1,000円/tonを下回 り，750円/ton まで低下する。

この補助金によって，酪農家の負担がどれだけ削減される か算出する。Table 6 に補助金額と酪農家の負担削減額を示 す。なお，消化ガス発電設備の償却期間を耐用年数と等しい

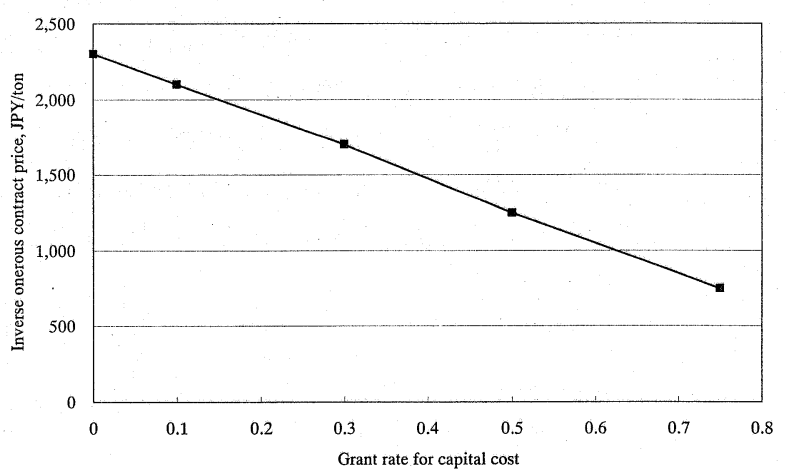

Fig. 8 Inverse onerous contract price as a function of subsidy for capital cost

Table 6 Subsidy for facilities and cost the reduction in farmer's payment

\begin{tabular}{c|c|c|c|c}
\hline Grant rate & $10 \%$ & $30 \%$ & $50 \%$ & $75 \%$ \\
\hline Subsidy (A) (10 $\left.{ }^{8} \mathrm{JPY}\right)$ & 3.3 & 10.0 & 16.7 & 25.1 \\
Reduction in farmer's & 4.7 & 14.2 & 25.0 & 32.3 \\
payment (B) (10 JPY) & & & & 129 \\
B / A (\%) & 142 & 142 & 150 & 129 \\
\hline
\end{tabular}


20 年と設定し，酪農家が支払うべき毎年の処理料の支払額は 変わらないものとして，20年間にわたって削減された金額を 現在価値に換算して酪農家の負担削減額を算出している。

すべての補助率で負担削減効果が $100 \%$ 超え，補助した金 額よりも酪農家の負担削減額が大きい。つまり, 酪農家の処 理コストに直接補助を行う(たとえば, 補助率 $30 \%$ の場合, 酪 農家が2,300 円/ton 支払うべきところを 1,700 円/ton の支払 いに軽減する）よりも設備建設に補助を行って逆有償価格を 低下させたほうが大きな効果が得られる。酪農家の負担は補 助金額の拈よそ1.3〜 1.5 倍削減され，補助率 $50 \%$ に抢いて費 用対効果が最大となる結果が得られた。建設費への補助率が $50 \%$ ま゙は, 補助率の増加につれてバイオマス発電コストが 低下し，導入が促進される。一方で，75\%の場合には発電コ ストの優位性が $50 \%$ の場合と比べて変わらなかった。した がって，補助率を50\%以上に設定する場合には，逆有償へ補 助した方が費用対効果としては有効であるといえる。

\section{5. 結 論}

本研究では, 地域電力供給システムを考案し, 対象地域の 地域特性を考慮し, システムの運用特性の解析やシステムの 導入により地域に及ぶ影響評価を行い，以下のことが明らか となった。

・再生可能エネルギーのなかで風力発電と木質バイオマス発

電は導入支援策がなくともエネルギー利用される。

・風力発電と木質バイオマス発電と系統電力によって地域電 力需要のほとんどが賄われる。

・考案した地域電力供給システムの導入により，二酸化炭素 排出量，エネルギーコストがともに削減され，それぞれ65 \%, 15\%の削減が可能である。

・畜産バイオマス利用技術は，他の発電技術に比べ，コスト が高いため, 畜産バイオマスを利用する電力供給はほとん ど行われない。

導入支援策がない場合，利用技術の経済性が低いために畜 産バイオマスの利用が進まない。畜産バイオマスの利用拡大 のためには，利用技術の経済性を高める施策が必要である。畜 産バイオマスの利用技術は単なる発電技術ではなく，廃棄物 処理技術としての側面も持っている。したがって，廃棄物処 理の観点から利用技術の経済性を高める施策を考案し，導入 支援策の評価を行った結果，以下のことが明らかとなった。 ・本研究では, 逆有償で家畜粪尿を引き取り処理する場合を 想定し解析した結果，逆有償価格が2,300円/tonのときに 対象地域で発生するほとんどすべての家畜糞尿を処理でき ることが明らかとなった。

・処理料の付加は酪農家の負担を増大させるために，それを 軽減させる施策が必要である。本研究では, 設備に対する 補助を行う場合, 逆有償価格の低減が可能となり, 補助し た金額以上に酪農家の負担を軽減することができることを 明らかにした。

本研究では, 再生可能エネルギーを中心とした地域電力供 給の可能性を示した。現行の法律や規制では, 本研究で考案
したシステムを実現する際には，電気主任技術者の選任など さまざまな要件を満足する必要がある。しかし，本システム が実現した場合は，環境負荷が低く，経済性の高い電力供給 を行うことが可能である。小規模分散型電源が，長期的に $\mathrm{CO}_{2}$ 削減や安定的な地域産業の育成, 保持に繋がる可能性が示さ れた。

\section{謝 辞}

本研究の遂行にあたり，葛巻町エネルギー政策課の方々に 大変有意義なご意見をいただき，ここに謝意を表します。原 稿の作成にあたり，伊藤吉紀氏（博士課程在学）の支援を受 けたことに感謝します。

\section{文 献: References}

1）岩手県, 平成 14 年度版 岩手県統計年鑑, (2003): Iwate Prefecture, Statistical Yearbook of Iwate Prefecture, (2003)

2）葛巻町, 暮巻町統計書(平成13年度版), (2002):Kuzumaki town, Statistical Book of Kuzumaki Town, (2002)

3）葛巻町, 葛巻町新エネルギービジョン，(1999):Kuzumaki town, Kuzumki New Energy Vision, (1999)

4) A. Lamont, User's Guide to the META • Net Economic Modeling System, (1994), Lawrence Livermore National Laboratory, Livermore, $\mathrm{CA}$

5）秋田県, http://www.pref.akita.jp/rinseika/info/148_6_1.htm (アクセス日 2004.3.5) : Akita Prefecture, http://www.pref. akita.jp/rinseika/info/148_6_1.htm (last access date 2004.3.5)

6) EPRI, U.S. Department of Energy, Renewable Energy Technology Characterizations, (1997), TR-109496

7) 竹本修明, RITE NOW, 35, 19 (2000) :Takemoto, S., RITE NOW, 35, $19(2000)$

8) U.S. Department of Energy, Energy Information Administration, Assumptions to the Annual Energy Outlook 2003, (2003), DOE / EIA-0554(2003)

9）中川悦光, 産業と環境, 32, 1, 38-42 (2003) :Nakagawa, Y., Sangyou to Kankyou, 32, 1, 38-42 (2003)

10）葛巻町, 葛巻町バイオマスエネルギー導入可能性調査報告 書, (2000) : Kuzumaki town, Feasibility Study of Biomass Energy in Kuzumaki, (2000)

11) 新エネルギー・産業技術総合開発機構 (NEDO), 新エネル ギー関連データ, http://www.nedo.go.jp/nedata/14fy/01/ g/0001g003.htm(アクセス日 2004.3.5) : New Energy and Industrial Technology Development Organization, Data Concerning New Energy, http://www.nedo.go.jp/nedata/14fy/ 01/g/0001g003.htm, (last access date 2004.3.5)

12）新エネルギー・産業技術総合開発機構(NEDO), 新エネル ギー関連データ, http://www.nedo.go.jp/nedata/14fy/03/ g/0003g002.htm(アクセス日 2004.3.5): New Energy and Industrial Technology Development Organization, Data Concerning New Energy, http://www.nedo.go.jp/nedata/14fy/ 03/g/0003g002.htm, (last access date 2004.3.5) 
13）山口県，森林バイオマス低コスト供給システムの構築に関 する調査報告書, (2003): Yamaguchi Prefecture, Feasibility Study on Supply System of Woody Biomass Resources with Lower Cost, (2003)

14) 東北電力, 電気料金単価表, (2002): Tohoku Electric Power Company, Electricity Tariff, (2002)
15）東北電力，環境行動レポート 2001, (2001):Tohoku Electric Power Company, Environmental Action Report 2001, (2001)

16) H. Mälkki, Y. Virtanen, Selected emissions and efficiencies of energy systems based on logging and sawmill residues, Biomass and Bioenergy, 24, 321-327, (2003) 